\title{
READER EXPECTATION AND ETHNIC RHETORICS: THE PROBLEM OF THE THE PASSING SUBALTERN IN WHO WOULD HAVE THOUGHT IT?
}

\section{Pascha A. Stevenson \\ University of Nebraska, Lincoln}

Mrs. Norval... hoped...Lola might be now all black or all white, no matter which, only not with those ugly white spots.

- Who Would Have Thought It? 1872 (78)

But these snowy, equable and smooth spots... sometimes occur amongst our own people. I have myself had the opportunity of observing two instances of this kind...The skin of each was brownish, studded here and there with very white spots of different sizes.

- "Mulattos" The Anthropological Treatises of Johann Friedrich Blumenbach, 1865 (220)

As illustrated by these two excerpts, the "mixed blood" provoked in Johann Friedrich Blumenbach, as it does in María Amparo Ruiz de Burton's Mrs. Norval, a kind of tension, a 
sometimes explicit, often insidious fear of racial unreadability and its implications for white domination. ${ }^{1}$ Pauline E. Hopkins, a little less than twenty years after Ruiz de Burton published her second novel, would ably demonstrate with characters such as Sappho Clark and Reuel Briggs, the unique capacity of the mulatto/a to disrupt the color line and refute popular and scientific thought about the "innate" differences between the races. ${ }^{2}$

While Ruiz de Burton's central figure, Lola Medina, also functions as a kind of disruptive mulatta, initially confounding carefully constructed racial boundaries, she ultimately slips out of her "passing" (usurped?) role as subaltern and into the role of "pure white" imperialist with disappointing ease. ${ }^{3}$ The potential realized by Hopkins' characters is not equaled in Who Would Have Thought It? Admittedly even an interrupted color line must leave enough of the racial boundary intact for the disruption to be readable. As Samira Kawash explains, "the very notion of hybridity is already predicated on conditions named by the essentializing division it seeks to counter, that is, the color line" (5). A truly disrupted line, in other words, is one exploded into invisibility such that the usual terms for racial quantification - mixed blood, biracial, mulatto/a and so on - become meaningless. Neither Hopkins' nor Ruiz de Burton's characters do that. Still, Lola Medina eventually manages to actually galvanize the color line, to make a startling case for white prerogative, and, I would posit, vies for the author's membership in the upper strata of a spurious racial hierarchy disseminated by some of the nineteenth century's most revered scientific minds. ${ }^{4}$ Such racial bargaining bears scrutiny, especially in light of the kinds of expectations contemporary readers tend to have of texts authored by persons of color.

In order to understand the nature of such "expectations," allow me to shift my focus for a moment. At the height of the Harlem Renaissance, as increasing numbers of African American authors finally began to receive the notoriety they deserved, W.E.B. Du Bois lamented. He lamented that black authors had begun to rail against the artistic bind of racial uplift and preferred rather to write what they knew, no matter how "unseemly" that might be. For Du Bois asserted throughout his Criteria of Negro Art (1926) that art and propaganda were one. He had earlier contended in The Souls 
of Black Folk (1903) that the beauty revealed to the black artist "was the soul-beauty of a race which his larger audience despised" (616). That this said "soul-beauty" might take an "uncultured" form, the rural black vernacular for example of Zora Neale Hurston's fiction, troubled Du Bois not so much because he failed to see its artistic splendor but because he was acutely aware of the pressure on black art to prove to white America (that "larger audience") the personhood of African Americans. ${ }^{5}$ What Du Bois articulated, the conflict over free art verses racial propaganda, has existed since Phillis Wheatley took pen to paper and continues still to find its way into the matrix of reader/writer relationships, especially where ethnic literature is concerned.

Persistent has been the reader expectation that the entire rubric of ethnic literature function as agent of the subaltern, and the subaltern is often conceived of as both author and subject within ethnic discourse. It is frequently assumed that ethnic writers will devote their art to racial uplift or social reformation through heart-of-gold and hardship stories, and there is discomfort when they do not, thus the outcry at Alice Walker's depiction of black males in The Color Purple. ${ }^{6}$

As a Latina, I have had the opportunity to observe the expectations people tend to have of my writing, of me, and consequently of ethnic texts in general. My students, for example, often seem to expect that ethnic writers will talk of nothing but race (and that somewhat defensively), that their stories will focus exclusively on pain, alienation and poverty. When we read writers such as Julia Alvarez who is both Latina and comes from an elite socioeconomic background, they are surprised, even shocked. ${ }^{7}$ Ethnic rhetorics, I believe, function within a web of expectation rooted in a kind of identity politics, a highly problematic template in that it misreads at the very least and refuses to read at its worst. The growing emphasis upon racial and ethnic diversity in our college classrooms is certainly welcomed by me, but conceptually, the boundaries of what has become rather simply known as "diversity" need a good deal of stretching, for as Victor Villanueva Jr. warns, "history and culture alone do not make for a political sensibility... such a view is reductive of the complex combinations of cultures and histories in American minorities, and...multiculturalism alone 
can be deceptive in that it suggests a friendly pluralism that does not exist outside the classroom" and, I would add, sometimes not even within it (623).

A diversity agenda, it seems to me (though with important exceptions), still too often consists of the benevolent attempt by an enlightened white America to include in the stories it tells, the travails of "darker" people. Automatically conflating ethnic minority and subaltern effectively circumscribes racial minorities within a narrow category that ultimately reinforces Anglo hegemony. This conflation may in part do the important work of recognizing wrongs and hardships, but it can also effect the comfort of the majority group by containing brownness within the rubric of hardship, ignorance, victimization and one-dimensional valorization. Complicating this reductive view as authors such as Alice Walker and Ruiz de Burton have done (each in radically different ways) generates discomfort in every corner, yet that discomfort is an important piece of business in the ongoing effort to "humanize" ethnic peoples in the United States. The very disturbing nature of the racial bargaining in which Ruiz de Burton participates compels us to problematize the tired conceptualization of ethnic rhetoric as the gesture of the subaltern. In short, sometimes ethnic voices are elitist, powerful, mean, racist, sexist, as well as loving, noble, disenfranchised, hurt, victimized, and so forth. A real appreciation for the complexity of this picture is vital to the total humanization of persons of color.

I will turn now to Ruiz de Burton's text for illustration of the "racial bargaining" to which I refer. Cheryl I. Harris reminds us that "In a society structured on racial subordination, white privilege became an expectation and...whiteness became the quintessential property for personhood" (qtd. in Ginsberg 7). Right on cue, Ruiz de Burton's Who Would Have Thought It? features a young heroine whose racial inscrutability compels those around her to question her "personhood." In chapter eleven, Lola "was decidedly too black and too young for" her white love interest "Julian Norval to take a fancy to her," but by chapter twenty-one, her spots are all but gone and Julian's heart is hers (51). Whiteness gives Lola access to everything she is denied as a black woman. The perplexity is that Ruiz de Burton seems to give her approbation to this state of 
affairs, not as an unfortunate historical truth, but as a proper race - class alignment.

I am driven to this conclusion by the innumerable instances in which the author identifies "pure Spanish blood" with whiteness, by the obvious fact that Ruiz de Burton enters into Lola's color anxiety all too enthusiastically. Indeed Lola's color anxiety itself is worth examining, for while she and the explicitly racist Mrs. Norval seem to be diametrically opposed to one another where race is concerned, actually Lola, our sympathetic protagonist, is just as repulsed as any of the other characters by her dark skin. Instance the scene in which Lola and Julian first reveal their love for one another. Lola tells Julian: "I didn't care whether I was thought black or white by others, I hated to think that you might suppose I was Indian or black. But I did not say anything to you because I thought you might laugh at me, and not believe me" (100). A fear of rejection by her beloved Julian may inform Lola's self-loathing in this scene, but clearly she betrays genuine disgust for black skin when she tells Julian in that same chapter that her mother "also was made to stain her lovely white skin all black" (100). Julian's immediate response is to explain to Lola that she is wrong, for his father "already told me that you are of pure Spanish descent" (100) [my emphasis].

Lola detests the blackness of her skin, of her mother's skin because it masks the imperial truth of her "pure Spanish descent," and why always "pure"? Does not Ruiz de Burton evoke the one drop rule to convince us that Spanish blood is white blood, pure and devoid of darkness? Is this not why Lola's skin becomes whiter than white, her mother's hut snowy white, her father's eyes blue? "Cultural logic," explains Elaine K. Ginsberg, "presupposes a biological foundation of race visibly evident in physical features such as facial structures, hair color and texture, and skin color" (4). Blood, and particularly the myth of "white" blood, simply functions as a metaphor for all the physical qualities which gain one access to property, freedom, power.

Perhaps the real passing figure in this text is María Amparo Ruiz de Burton. I suggest that Lola's journey from darkness to whiteness commands metaphorical significance as Ruiz de Burton's own journey from darkness to whiteness, from Mexican to Caucasian, 
from subaltern to imperialist. She seems to be trying, with this text, to forge out of its discourse some sort of reality wherein she too is a white person, able to stand amidst other white people and heave a collective sigh of relief that they are not dark. For the black - white binary makes no allowance for brownness; one is either white and privy to the heritable privileges which accompany whiteness, or one is something else: brown, black, red, yellow; the exact color may not actually be as important as the mere absence of whiteness. Sánchez and Pita contend that the "construction of upper-class Latino/as as white" is "a perhaps defensive - though not defensible - move on Ruiz de Burton's part, in view of the fact that Congressional records of the period refer to Mexicans in the Southwest as 'a mongrel race'" (xx). Despite Ruiz de Burton's hyper-avowel that "pure Spanish blood" is "white blood," or rather because of it, one cannot help but assume that she was aware of the popular racial hegemony in which a Mexican would not have figured amongst the highest members.

Let us return to Blumenbach and his "Table of Colours" which lists seven different color categories: black, sub-black, copper-coloured, red, brown, light brown, and white. This infamous table constructs a kind of continuum with white and black at opposite ends. The highly influential Blumenbach would have apparently taken issue with Ruiz de Burton's conflation of white and Spanish blood, for he lists Spanish, not under "white" with Swedes, Danes, English etc., but under the second heading "light brown" (367). Although Blumenbach's explicit purpose in creating such categories is strict classification, not stratification, his implicit purpose is of course to provide a "scientific" basis for white supremacy. Everywhere in The Anthropological Treatises he points to the superiority of the fairer races over the darker ones, rendering such categories hierarchical indeed. "It has long since been observed" says Blumenbach, "that far the greater number of men in mad hospitals and jails have black hair" (224). He invites us to compare the "flattened face" of the Chinese with the "symmetrical and particular beauty...common amongst us Europeans" (229). The examples are endless, and the point is that Sánchez and Pita make sense when they interpret Ruiz de Burton's tenacious alignment of Spanish and white blood as a defensive reaction to a white supremacist culture in which she 
probably would not be deemed white.

"Talk of Spanish women being dark!" says Mattie, one of Lola's few allies, "can anything be whiter than Lola's neck and shoulders?" (232). Because Mattie's credibility steadily increases as the novel unfolds, we may be certain that we are meant to believe her when she says first that there is talk of Spanish women being dark, and second that such talk betrays a profound degree of ignorance, for clearly Spanish women are not dark - instance Lola's neck and shoulders. When Mrs. Cackle, on the other hand, exclaims that to her "they are all alike - Indians, Mexicans, or Californians - they are all horrid," we are not to invest any confidence whatever in her ability to perceptively discern the world around her (11).. The very fact that "they" are all alike to her is proof positive that the opposite must be true, for the Cackles are buffoons. Lastly, when the Reverend Hackwell expresses his disgust at the collapse of his plans to steal away with Lola, he abuses her father as the "'accursed blue-eyed Mexican'...Who ever heard of a blue-eyed Mexican? I wish I could choke the rare specimen" (253). By now we know that Hackwell is an absolute scoundrel and are not encouraged by the author to seek, from his mouth, truth or enlightenment. That he finds it incredulous, therefore, that a Mexican should have blue eyes, that he thinks such a man a "rare specimen," should certainly lead the reader to the opposite conclusion.

What these three instances illustrate is Ruiz de Burton's awareness that Mexicans, that Spaniards were perceived by the "ignorant masses" as nonwhite "others." Through these three characters she communicates her understanding of how her own racial/class position is conceived by the cultural consciousness. She is Spanish and therefore dark; she could not have blue eyes unless through some freak of nature; she is "as bad as the Indians." In short she is not white. In light of the knowledge which these three characters tell us Ruiz de Burton must have had about the position of Mexicans within a predominately white society, her insistence upon the equality of Spanish and white blood, upon the literal "sameness" of it, appears all the more defensive. In his excellent article on the politics of race in Who Would Have Thought It?, Jesse Alemán argues that Ruiz de Burton's preoccupation with pure Spanish blood is driven by a historically prevalent and 
politically advantageous desire to separate her Mexican self from other nonwhite races, such as American Indians, in order to appear whiter by way of contrast (97). Alemán further posits:

Indeed, the contradiction between Mexican American dispossession and claims to white citizenship rights remains a thorn in the side of Chicana/o literary history...Ruiz de Burton, as with many of her upper-class criollo contemporaries, had to negotiate a new position within an emerging American ruling class that by no means readily embraced California Mexicans. (97-98)

The overwhelming consensus among critics, including Alemán, is that Ruiz de Burton clearly bargains for whiteness through a body of work that, by turns, renounces, exposes, and reinforces the racism of her day.

However the matter of reading the author through her text, her history, is tricky at best. Perhaps we are influenced by Ruiz de Burton's ties to the Northeast, her many years residence there, her marriage to a white U.S. army officer, the publication of Who Would Have Thought It? in Philadelphia (Sánchez and Pita viii). Perhaps these facets of her personal history compel critics to view her self-positioning as already pseudo-white because of her connection to white American society. But one could just as readily perhaps highlight her separation from American whiteness as evidenced, in part, by her impassioned devotion to her own race of disaffected Californios. As she does in many of her letters, Ruiz de Burton expresses such sentiments in an 1859 letter to Platón Vallejo: "it is my most ardent wish that all Californians may cherish forever in their bruised hearts that loyal attachment to their own race" (157). Ultimately, as Who Would Have Thought It? illustrates, the boundaries between racial categories are, in some respects, permeable, even at the most racially segregated of historical moments. Ruiz de Burton, therefore, may well function simultaneously as the white Latina suffering from what Raymund Paredes calls "hacienda syndrome," and the disaffected, nonwhite, Californio Latina nursing the wounds of racial prejudice. ${ }^{8}$ The extent to which critical conclusions about Ruiz de Burton's views of race have been influenced by knowledge of her personal 
history, her Northeast connections, her California roots, is difficult to determine. I believe the literary evidence for Ruiz de Burton's racial bargaining supersedes personal history, but the two are admittedly intertwined in the scholarship.

I do know the one thing I do not want to do in my analysis of Who Would Have Thought It? is operate from a kind of self consciously political position that looks for ethnic authors to make a requisite set of subversive moves, in whatever manner of writing they do - in short, to raise social awareness or speak back to their oppressors. I wholly reject the widespread expectation that writers of color always produce work which addresses racial issues, as if they must speak from racial/cultural positions exclusively. Such a requirement is reductive and insulting; it essentially limits ethnic voices to a kind of discourse of indignance and victimization. And while I have no desire to critique that discourse itself (it is often one of profound value and power), I do object to the expectation that ethnic authors always employ it. "'Minority' scholars are made to feel it is their scholarly duty to show how resistance to authority is manifest through subversion" says Ruth Spack in "The (In)Visibility of the Person(al) in Academe" (21). We are conditioned, Victor Villanueva Jr. reminds us, to conceive of minorities as subalterns, as oppressed and to expect their writing, therefore, to adhere to a kind of pattern: to create a new history, to raise "a mass consciousness to oppression," to refuse to accept oppression, to document the emergence of the "conscious intellectual" (627).

Both Spack and Villanueva lament the limiting force of identity politics as it constructs a narrow ideological paradigm within which ethnic authors are expected to operate. Such expectations are indeed at the center of my critique, but I also want to qualify that criticism to some extent. For the same "good politics" that fitted Villanueva for his first job in academe, "the minority for the minority-sensitive job. The best-qualified: a brown slum kid, performing research on what happens to minorities in college writing classrooms," also tend to issue from a well intentioned desire to see the subaltern achieve some kind of agency (622). The written word, after all, has the potential to serve as a vehicle for class shift and the righting of terrible wrongs. Nevertheless, I want to be careful of bringing these kinds of expectations to a 
text written over one hundred years ago, yet I know that as such a text makes its way into the hands of contemporary readers, the convergence of Ruiz de Burton's and our historical locations will have to be negotiated. I also want to be careful of bringing such expectations to a text based solely upon the ethnicity of its author - this would constitute essentialization at its worst.

Furthermore, it is Ruiz de Burton who broaches the issue of race, of what it means to be white, of what it is to be black, and engaging her within that debate, I cannot help but feel, from a chiefly personal perspective, disappointed with her appropriation of the fallacious language of white blood purity. Not even Pauline E. Hopkins' explicitly passing figures join in the derision of African Americans; their relationship to both the race they pass out of and the one they pass into is complex; it negotiates both push and pull factors. Never does passing for white mean passing for white supremacist for characters like Reuel Briggs. But for Lola Medina and for Ruiz de Burton, on some level at least, such seems to be the case.

$\infty \infty \infty$

The diversity politics now so popular makes little room for the likes of María Amparo Ruiz de Burton, or at least for the facets of her work I have discussed here, and, an over-investment in the minority-as-subaltern narrative would foreground the manner in which Lola is victimized because of her race rather than the manner in which she and Ruiz de Burton function as racists. The complexity of Ruiz de Burton's position in this text explodes the reductive myth of the "noble savage," which seems to me still too much among us, while simultaneously deeply disturbing us with its implicit and explicit white supremacy. ${ }^{9}$ Here is a minority authored text which squirms its way into whiteness, often deriding (and consequently separating itself from) the "darker" races. Who Would Have Thought It? provides an important example of the kind of text a "diversity" agenda might teach us to resist or misread. But it is all the more important for us not to resist it because of its complexity, because of its ability to unsettle its readers with a warning against one dimensional reduction of ethnic literature to the "subaltern voice" - moving in its pain and valor. This subaltern voice (a contradiction in terms I know) exists and is important, but to 
the extent that it is appropriated to contain and essentialize ethnic rhetorics, a text like Ruiz de Burton's proves equally important.

Ruiz de Burton's reticence with regard to compromising the color line is troubling, but the kinds of assumptions about women writers, about minority writers which inform this reaction should also be examined. María Amparo Ruiz de Burton should not be stripped of her historical location, human complexity or disturbing fallibility, nor should her text be made to yield its historical context to political salience. Ruiz de Burton "has become a key figure in the recovery of nineteenth-century Mexican American literature specifically and the reconfiguration of nineteenth-century American literary culture more generally" say Amelia María de la Luz Montes and Anne Elizabeth Goldman in their excellent collection on the same subject (1). They further credit Ruiz de Burton with frank and unique (for her time) acknowledgment of feminine desire, "emancipation from sentimentalism and a sharply discerning eye for political and social hypocrisy (1). The immensity of her contribution to American and American Ethnic literature can hardly be denied, and acknowledging, as many critics have done, her literary (and perhaps personal) quest for whiteness as a companion piece to the condemnation of Mexican stereotypes, does little to detract from that accomplishment. ${ }^{10}$ Rather, I hope only to employ Ruiz de Burton's work in yet another capacity, that of illustrating the real diversity of ethnic authors, their humanity, their fallibility, and, through it, our own sometimes narrow conceptions of who such authors are allowed to be, what they are permitted to say. In this sense, Ruiz de Burton has revealed yet another stereotype, that of the ethnic subaltern.

In the end though, I cannot help but lament the passing of Lola Medina into whiteness as the erasure of Ruiz de Burton's own Mexican identity, for (fallacious biology aside) "white blood" is not the same as "Spanish blood," and of this fact she seems quite painfully aware.

\section{REFERENCES}

Alemán, Jesse. "'Thank God, Lolita is Away From Those Horrid Savages': The Politics of Whiteness in Who Would Have Thought It?" María Amparo Ruiz de Burton: Critical and Pedagogical. 
Perspectives. Ed. Amelia María de la Luz Montes and Anne Elizabeth Goldman. Lincoln: Nebraska UP, 2004. 95-111.

Blumenbach, Johann Friedrich. The Anthropological Treatises. of Johann Friedrich Blumenbach. Trans. Thomas Bendyshe. London: Longman, 1865.

Du Bois, W.E.B. The Souls of Black Folk. The Norton Anthology of African American Literature. Ed. Henry Louis Gates Jr. and Nellie Y. McKay. New York: W.W. Norton, 1997. 613-740.

Ginsberg, Elaine K. "The Politics of Passing." Introduction. Passing and the Fictions of Identity. Ed. Elaine K. Ginsberg. Durham: Duke UP, 1996. 1-18.

Kawash, Samira. Dislocating the Color Line: Identity, Hybridity, and Singularity in African-American Narrative. Stanford: Stanford UP, 1997.

Ruiz de Burton, María Amparo. "Letter to Platón Vallejo." 23 April 1859. Conflicts of Interest:The Letters of María Amparo Ruiz. de Burton. Ed. Rosaura Sánchez and Beatrice Pita. Houston: Arte Público, 2001. 156-58.

-. Who Would Have Thought It?. Houston: Arte Público, 1995. Sánchez, Rosaura and Beatrice Pita. Introduction. Who Would Have Thought It?. By María Amparo Ruiz de Burton. Houston: Arte Público, 1995. vii-lxv.

Spack, Ruth. "The (In)Visibility of the Person(al) in Academe."

College English 59 (1997): 9-31.

Villanueva, Victor, Jr. "Considerations for American Freireistas." Cross-Talk in Comp Theory: A Reader. Ed. Victor Villanueva, Jr. Urbana: NCTE, 1997. 621-37.

\section{FOOTNOTES}

1. Blumenbach's AnthropologicalTreatises of 1865 marksagrowingpreoccupation in the 19th century - that of classifying the natural world. With regard to race, this text, originally Blumenbach's dissertation, is actually rather forward thinking in its assertion of nonwhite peoples as human. But Anthropological Treatises falls prey to the racism of its day when, as with its contemporaries, Robert Knox's The Races of Men (1850) for example, classification becomes stratification, and division gives way to hierarchical ordering.

2. Sappho Clark is Hopkins' lead character in Contending Forces (1899) and likewise Reuel Briggs in Of One Blood (1902). Both figures are characterized as having "mixed blood" and can pass for white but remain, throughout the stories, passionately (if not always explicitly) faithful and sympathetic to their 
black heritage.

3. I take the term "subaltern" from Gayatri Spivak's seminal essay "Can the Subaltern Speak?". In it she defines subaltern as s/he for whom others must speak, s/he without even the power to make him/herself heard. Interestingly, Spivak complicates this definition with an acknowledgment of the range of subaltern stereotypes now firmly in circulation. She writes: "The banality of leftist intellectuals' lists of self-knowing, politically canny subalterns stands revealed; representing them, the intellectuals represent themselves as transparent" (275). This essay is widely available, but I take it from Nelson and Grossberg's Marxism and the Interpretation of Culture published by Illinois UP (1988).

4. I refer here to Charles Darwin, Herbert Spencer, Blumenbach of course, and Robert Knox. I do not claim that all of these mean were explicitly racist in their work, rather that, to varying degrees, their work participated in and at times perpetuated the myth of the superiority of whiteness.

5. By 1926 Du Bois had become profoundly incensed at the turn the New Negro movement had taken. This disagreeable though popular new direction became emblematized by what he termed the "Van Vechten school" by which moniker he meant to capture what he saw as the debased nature of the representation of African-Americans in works such as Carl Van Vechten's Nigger Heaven (1926). Ten years later Zora Neale Hurston's Their Eyes Were Watching God (1937) came under similar fire as further evidence that black art had made its way back to the shame of the minstrel show. An excellent and concise overview of Du Bois' aesthetic and political standards can be found in the Encyclopedia of the Harlem Renaissance published by Routledge (2005). See also Bell, Grosholz and Stewart's W. E. B. Du Bois on Race and Culture also published by Routledge (1996).

6. For further exploration of the debate over Alice Walker's representation of black men in The Color Purple, see Alvin F. Poussaint's February 1993 article in Ebony, "Enough Already!". See also Whitaker and Cobb's May 92 Ebony article, "Alice Walker: Color Purple Author Confronts Her Critics and Talks About Her Provocative New Book," in which Walker speaks candidly about the pressure to compromise art and personal truth for political expediency.

7. In her 1999 autobiography entitled Something to Declare (Plume), Julia Alvarez details the highly privileged life she and her family enjoyed in her home country of the Dominican Republic before immigrating to the United States to escape Trujillo's bloody tyranny. The young Alvarez lived a life of abundance, with an army of servants, good food, fine cloths and powerful connections. This is an image of Latino/a immigrants seldom circulated in the popular consciousness. 8. I take the term "hacienda syndrome" from Raymund Paredes" "The Evolution of Chicano Literature" in Three American Literatures: Essays in Chicano, Native American, and Asian American Literature for Teachers of American Literature, edited by Houston Baker Jr. and published by MLA in 1982. Paredes uses this term to refer to the contextually expedient conflation of whiteness with Latino/ a racial identity.

9. I take the term "noble savage" from Jean-Jacques Rousseau's famous work, "Discourse on the Origins of Inequality," in which he describes primitive man 
not as a precursor to modern man but as his companion. "Savages," said Rousseau, are still very much among us; they are sometimes the darker races, sometimes rural cultures, always without formal education, the "proper" use of language, and so on. This is, in short, a dubious representation of primitivism, for while it objectifies the "savage in bizarre and uncomfortable ways, it also sets him/her above civilized man as one closer to and in greater harmony with nature. Rousseau saw this harmony as something to be revered, perhaps even envied, but the essentializing tendencies of his theories are obvious. See Masters and Kelly's Collected Writings of Rousseau published by UP of New England (1992).

10. For further reading on Ruiz de Burton's contribution to American and Ethnic American literature, see Amelia María de la Luz Montes and Anne Elizabeth Goldman's collection María Amparo Ruiz de Burton: Critical and Pedagogical Perspectives published by Nebraska UP (2004). The collection offers a wide range of critical and pedagogical perspectives on Ruiz de Burton's work and life, but the introduction composed by Montes and Goldman does a very nice job of broadly assessing Ruiz de Burton's contribution to the American literary tradition. 